\title{
Influence of intentional ankylosis of deciduous canines to reinforce the anchorage for maxillary protraction
}

\author{
Luís Fernando Castaldi Tocci, Omar Gabriel da Silva Filho², Acácio Fuziy ${ }^{3}$, José Roberto Pereira Lauris ${ }^{4}$
}

Introduction: This retrospective cephalometric study analyzed the influence of intentional ankylosis of deciduous canines in patients with Class III malocclusion and anterior crossbite, in the deciduous and early mixed dentition stages, treated by orthopedic maxillary expansion followed by maxillary protraction. Methods: Lateral cephalograms of 40 patients were used, divided in 2 groups paired for age and gender. The Ankylosis Group was composed of 20 patients (10 boys and 10 girls) treated with induced ankylosis and presenting initial and final mean ages of 7 years 4 months and 8 years 3 months, respectively, with a mean period of maxillary protraction of 11 months. The Control Group comprised 20 patients (10 boys and 10 girls) treated without induced ankylosis, with initial and final mean ages of 7 years 8 months and 8 years 7 months, respectively, with a mean period of maxillary protraction of 11 months. Two-way analysis of variance and covariance analysis were applied to compare the initial and final cephalometric variables and the treatment changes between groups. Results: According to the results, the variables evidencing the significant treatment changes between groups confirmed that the intentional ankylosis enhanced the sagittal response of the apical bases (Pg-NPerp) and increased the facial convexity angles (NAP and ANB). Conclusions: The protocol involving intentional ankylosis of deciduous canines enhanced the sagittal response of the apical bases.

Keywords: Malocclusion. Angle Class III. Crossbite. Interceptive orthodontics.

Introdução: nesse estudo cefalométrico retrospectivo, analisou-se a influência da anquilose intencional de caninos decíduos em pacientes com má oclusão de Classe III e mordida cruzada anterior, nos estágios de dentição decídua e mista precoce, tratados com expansão ortopédica da maxila, seguida de tração reversa. Métodos: foram utilizadas telerradiografias em norma lateral de 40 pacientes, divididos em 2 grupos pareados por idade e sexo. O Grupo Anquilose foi constituído de 20 pacientes (10 meninos e 10 meninas) tratados com anquilose induzida e que apresentavam as idades médias inicial e final, respectivamente, de 7a 4m e 8a 3m, e o tempo médio de tração reversa de 11 meses. O Grupo Controle, composto de 20 pacientes (10 meninos e 10 meninas) tratados sem anquilose induzida e que apresentavam as idades médias inicial de 7a 8m e final de $8 \mathrm{a} 7 \mathrm{~m}$, e tempo médio de tração reversa de 11 meses. Foram empregadas as análises de Variância a dois critérios e de Covariância para comparar as variáveis cefalométricas inicial e final e as alterações de tratamento entre os grupos. Resultados: segundo os resultados, as variáveis que evidenciaram as mudanças de tratamento significativas entre os grupos confirmaram que o procedimento de anquilose intencional potencializou a resposta sagital das bases apicais (Pg-NPerp) e aumentou os ângulos de convexidade facial (NAP e ANB). Conclusão: o protocolo envolvendo a anquilose intencional de caninos decíduos potencializou a resposta sagital das bases apicais.

Palavras-chave: Má oclusão. Classe III de Angle. Mordida cruzada. Ortodontia interceptora.

${ }^{1} \mathrm{MSc}$ in Orthodontics, UNIMAR.

${ }^{2} \mathrm{MSc}$ in Orthodontics, UNESP.

${ }^{3}$ Post-Doc in Dentistry, FOB-USP.

${ }^{4}$ Full Professor, USP. PhD in Human Communication Disturb, University of São Paulo.
How to cite this article: Tocci LFC, Silva Filho OG, Fuziy A, Lauris JRP. Influence of intentional ankylosis of deciduous canines to reinforce the anchorage for maxillary protraction. Dental Press J Orthod. 2013 Jan-Feb; 18(1):94-102.

Submitted: April 18, 2010 - Revised and accepted: June 30, 2011

"The author reports no commercial, proprietary or financial interest in the products or companies described in this article.

Contact address: Luís Fernando Castaldi Tocci

Rua Carneiro Lobo, 570 - Conj. 1003 - Batel - Curitiba/PR - Brazil

CEP 80240.240 - E-mail: clinica@tocciortodontia.com.br 


\section{INTRODUCTION}

Some questions still challenge the scientific community concerning the Class III malocclusion: What will be the behavior of the face, and especially of the mandible, during growth? Will the facial growth perpetuate or worsen the skeletal discrepancy? There are no established responses to these questions, raising controversies among orthodontists concerning the indication of early treatment for the Class III malocclusion. ${ }^{1}$ The treatment prognosis and posttreatment stability depend on the skeletal pattern related with this malocclusion. ${ }^{16,18}$

Interceptive orthodontics (mechanics applied in the stages before the permanent dentition) has the general objective to optimize the development of occlusion. ${ }^{18}$ The treatment with maxillary protraction is more effective in patients with Class III malocclusion with maxillary retrusion, which account for nearly $60 \%$ of the cases, ${ }^{16}$ and hypodivergent growth pattern, ${ }^{13,15}$ explaining the increased professional interest for maxillary protraction. The orthopedic mechanics acts on the direction of spontaneous facial growth. ${ }^{16}$ If the treatment is initiated during the period of eruption of maxillary central incisors, it will contribute to stabilize the anterior relationship., ${ }^{9,13,15}$

Clinical results demonstrate that the utilization of maxillary protraction induces orthopedic and orthodontic effects that provide an important improvement in the occlusion and face (Table 1). The immediate favorable impact, though variable and individual, ${ }^{15}$ in the deciduous and mixed dentition stages are related to forward maxillary displacement, ${ }^{1,2,5,6,9-13,15,17,18,21,23}$ forward displacement of maxillary teeth, ${ }^{2,6,8,10,18}$ clockwise mandibular rotation with corresponding significant increase in the lower anterior facial height, ${ }^{5,10,18}$ and lingual tipping of mandibular incisors. , $3,3,9,16,18$

Orthodontists are aware of the importance to optimize the orthopedic effect of maxillary protraction, rather than the orthodontic effects. ${ }^{6}$ Within this context, the orthopedic maxillary expansion before maxillary protraction increases the effect of the face mask on the maxilla ${ }^{1,2}$ due to the increase in the transverse width, rupture of maxillary sutures and especially to the strong anchorage provided by the expander ${ }^{16}$ (Table 1).

The intentional ankylosis of deciduous canines has also been used with the primary goal to potentiate the orthopedic effects of maxillary protraction. ${ }^{18,19,20}$ This led to the need to scientifically analyze its utilization, because though biocompatible and accepted by the patients, ${ }^{19}$ it is an invasive procedure.

This study evaluated the immediate effects of maxillary protraction applied in the deciduous and early mixed dentition stages to respond to the null hypotheses if there is difference between the immediate results produced by orthopedic maxillary protraction mechanics, using or not the induced ankylosis to reinforce the anchorage.

Table 1 - Literature on the utilization of maxillary protraction (with facial mask) applied immediately after orthopedic maxillary expansion.

\begin{tabular}{|c|c|c|c|c|c|c|}
\hline AUTHOR & YEAR & ANCHORAGE & FORCE & USE & EFFECT & $\begin{array}{l}\text { CHANGE IN } \\
\text { POINT A }\end{array}$ \\
\hline Baccetti et al. ${ }^{1}$ & 1998 & $\begin{array}{l}\text { Fixed maxillary expander with acrylic } \\
\text { occlusal coverage }\end{array}$ & $227-397 \mathrm{~g} / \mathrm{side}$ & $24 \mathrm{~h}$ & Orthopedic/Orthodontic & $2.6 \mathrm{~mm}$ \\
\hline Baik $^{2}$ & 1995 & Hyrax & $300-500 \mathrm{~g} / \mathrm{side}$ & $12 \mathrm{~h}$ & Orthopedic/Orthodontic & $2 \mathrm{~mm}$ \\
\hline Gallagher et al. ${ }^{6}$ & 1998 & $\begin{array}{l}\text { Fixed maxillary expander } \\
\text { (slow expansion) }\end{array}$ & $\begin{array}{l}600-800 \mathrm{~g} / \\
\text { bilaterally }\end{array}$ & $12-24 h$ & Orthopedic/Orthodontic & 1 to $2 \mathrm{~mm}$ \\
\hline Kapust et al..$^{10}$ & 1998 & - & $\begin{array}{l}600-800 \mathrm{~g} / \\
\text { bilaterally }\end{array}$ & - & Orthopedic/Orthodontic & $2.3 \mathrm{~mm}$ \\
\hline McNamara Jr. ${ }^{12}$ & 1987 & $\begin{array}{l}\text { Fixed maxillary expander with acrylic } \\
\text { occlusal coverage }\end{array}$ & $397 \mathrm{~g} / \mathrm{side}$ & $24 \mathrm{~h}$ & Orthopedic/Orthodontic & 1 to $2 \mathrm{~mm}$ \\
\hline Ngan et al. ${ }^{14}$ & 1996 & Hyrax & $380 \mathrm{~g} /$ side & $12 \mathrm{~h}$ & Orthopedic/Orthodontic & $2 \mathrm{~mm}$ \\
\hline Ngan et al. ${ }^{16}$ & 1997 & Hyrax & $380 \mathrm{~g} / \mathrm{side}$ & $12 \mathrm{~h}$ & Orthopedic/Orthodontic & $1.9 \mathrm{~mm}$ \\
\hline Saadia, Torres ${ }^{17}$ & 2000 & Hyrax or Haas & $395 \mathrm{~g} /$ side & $8-14 h$ & Orthopedic/Orthodontic & $1.9 \mathrm{~mm}$ \\
\hline Shanker et al. ${ }^{18}$ & 2003 & Hyrax & $400 \mathrm{~g} / \mathrm{side}$ & $12 \mathrm{~h}$ & Orthopedic/Orthodontic & $2.4 \mathrm{~mm}$ \\
\hline Silva Filho et al. ${ }^{19}$ & 1998 & Haas & $350 \mathrm{~g} /$ side & $10-14 h$ & Orthopedic/Orthodontic & $2.5 \mathrm{~mm}$ \\
\hline Silva Filho et al..$^{20}$ & 2003 & Haas / Intentional ankylosis & $350 \mathrm{~g} / \mathrm{side}$ & $10-14 h$ & Orthopedic/Orthodontic & $2.5 \mathrm{~mm}$ \\
\hline Sung, Baik ${ }^{22}$ & 1998 & Fixed maxillary expander (rapid expansion) & $300-400 \mathrm{~g} / \mathrm{side}$ & Over $12 \mathrm{~h}$ & Orthopedic/Orthodontic & 1.7 to $2.8 \mathrm{~mm}$ \\
\hline Turley ${ }^{24}$ & 1998 & Hyrax and mandibular occlusal support & $150-600 \mathrm{~g} / \mathrm{side}$ & $14-24 h$ & Orthopedic/Orthodontic & $3.3 \mathrm{~mm}$ \\
\hline
\end{tabular}




\section{MATERIAL AND METHODS}

The sample was composed of 40 Brazilian Caucasian children aged 5 years to 8 years 11 months, in the deciduous and early mixed dentition stages, retrospectively selected from the files of the Postgraduate course in Preventive and Interceptive Orthodontics of the Hospital for Rehabilitation of Craniofacial Anomalies of University of São Paulo, at Bauru (HRAC-USPBauru), Brazil, among the records of 2,060 registered and treated patients.

The inclusion criteria were the following: 1- Brazilian Caucasian children in the deciduous and early mixed dentition stage; 2 - presenting Class III molar relationship; 3 - anterior crossbite; 4 - maxillary retrognathism with little or no mandibular involvement; and 5 - posterior crossbite in most cases. Patients with isolated mandibular impairment (prognathism) were not included.

The sample was divided into two groups of $20 \mathrm{pa}-$ tients (10 boys and 10 girls) matched for age and gender. The Ankylosis Group was composed of patients treated with induced ankylosis with initial $\left(\mathrm{T}_{1}\right)$ and final $\left(\mathrm{T}_{2}\right)$ mean ages of 7 years 4 months and 8 years 3 months, respectively, with mean period of maxillary protraction of 11 months. The Control Group was treated without induced ankylosis and presented initial mean age of 7 years 8 months and final mean age 8 years 7 months, with a mean period of maxillary protraction of 11 months.

In the Ankylosis Group, among the 20 patients, 16 presented posterior crossbite, being 9 girls and 7 boys, and in the Control Group 17 out of the 20 patients presented posterior crossbite, being 8 boys and 9 girls.

All 40 children were submitted to the same therapeutic protocol of rapid maxillary expansion with modified fixed Haas expander, with activation of the screw until rupture of the midpalatal suture or up to correction of the posterior crossbite, when present. The therapeutic groups were distinguished by the accomplishment of intentional ankylosis of deciduous canines as anchorage reinforcement. Immediately after completion of the active period of rapid maxillary expansion, the facial mask was placed using elastics delivering an approximate force of $500 \mathrm{~g}$ connected to hooks soldered at the anterior portion of the expander and bonded to the deciduous canines with resin. The patients were instructed to wear the facial mask for 16 hours/day.
The lateral cephalograms were obtained in centric occlusion, with the lips in relaxed and passive position. The anatomical tracings and identification of the dentoskeletal points were manually performed by a single examiner and digitized on a UMAX 1220S scanner connected to a computer NB HP Pavillion dv6120BR (3400, HD $60 \mathrm{~Gb}$, memory $512 \mathrm{Mb}$ ), with operational system Windows XP and software Radiocef Studio Radiomemory, version 1 - release 16, Belo Horizonte, MG, Brazil (Fig 1). Data were analyzed on this software, which also corrected the magnification factors of radiographic images, which ranged from 6\% to $9.8 \%$ according to the X-ray machine employed.

The cephalometric measurements selected are representative of the facial convexity (NAP, ANB), sagittal position of the apical bases (SNA, SNB, SND, SN.ANS, Co-A, A-NPerp, Pg-NPerp), mandibular and occlusal plane rotation (SN.GoGn, SN.Gn, SN.OP) and inclination of maxillary and mandibular incisors (1.NA, 1-NA, 1.SN, 1.PP, 1.NB, 1-NB, IMPA) (Table 4).

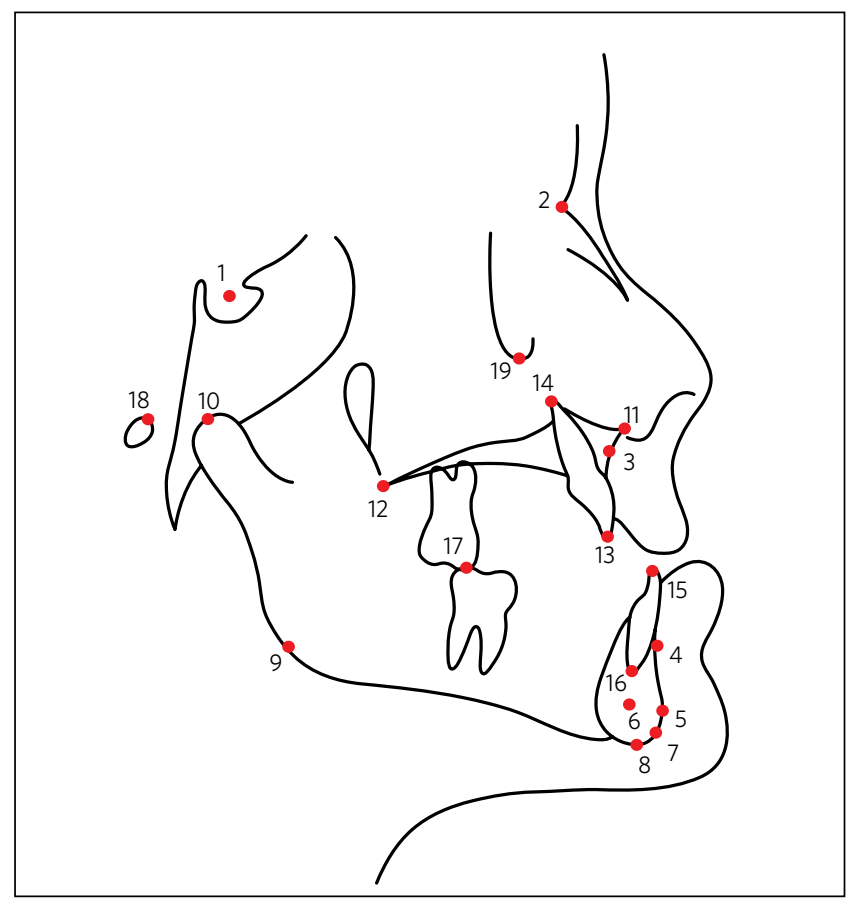

Figure 1 - Cephalometric points used on the lateral tracing: 1) S: sella turcica; 2) N: nasion; 3) A: subspinale; 4) B: supramentale; 5) Pg: pogonion; 6) D: geometric center of the symphysis; 7) Gn: gnathion; 8) Me: menton; 9) Go: gonion; 10) Co: condylion; 11) ANS: anterior nasal spine; 12) PNS: posterior nasal spine; 13) MxIE: incisal edge of maxillary central incisor; 14) MxIA: apex of maxillary central incisor; 15) MdIE: incisal edge of mandibular central incisor; 16) MdIA: apex of mandibular central incisor; 17) OCM1: mean occlusal contact between the maxillary and mandibular first molars; 18) Po: porion; 19) Or: orbitale. 


\section{STATISTICAL ANALYSIS}

\section{Method error}

For calculation of the intraexaminer error, at 20 days after the first tracing, 12 cephalograms of each group (30\% of the sample) were randomly selected for achievement of new tracings, identification of points and achievement of linear and angular measurements. The intraexaminer systematic error was evaluated by the paired $t$ test. The casual error was determined according to the Dahlberg formula (error $\left.=\left(\sum \mathrm{d}^{2} / 2 \mathrm{n}\right) 1 / 2\right)$, in which $d$ represents the difference between the first and second measurements and $n$ indicates the number of retraced cephalograms, according to Houston. ${ }^{7}$ The significance level adopted was $5 \%(\mathrm{p}<0.05)$.

The results of evaluations of systematic errors by the paired $t$ test and by the casual error measured by the Dahlberg formula are presented in Table 4.

Table 2 - Mean, standard deviation of two measurements, paired $t$ test and Dahlberg formula to evaluate the systematic and casual errors.

\begin{tabular}{|c|c|c|c|c|c|c|c|}
\hline \multirow{2}{*}{$\begin{array}{l}\text { measure- } \\
\text { ment }\end{array}$} & \multicolumn{2}{|c|}{$\begin{array}{c}\text { first } \\
\text { measurement }\end{array}$} & \multicolumn{2}{|c|}{$\begin{array}{c}\text { second } \\
\text { measurement }\end{array}$} & \multirow[t]{2}{*}{$t$} & \multirow{2}{*}{$\mathbf{p}$} & \multirow{2}{*}{ Error } \\
\hline & mean & SD & mean & SD & & & \\
\hline NAP & 3.77 & 6.54 & 3.65 & 6.41 & 0.621 & $0.538 \mathrm{~ns}$ & 0.79 \\
\hline SNA & 81.05 & 4.70 & 81.28 & 4.67 & 1.816 & 0.077 ns & 0.58 \\
\hline SNB & 79.24 & 4.62 & 79.41 & 4.59 & 1.705 & $0.097 \mathrm{~ns}$ & 0.44 \\
\hline ANB & 1.80 & 2.95 & 1.87 & 2.83 & 1.669 & 0.104 ns & 0.53 \\
\hline SND & 75.86 & 4.41 & 76.27 & 4.47 & 1.992 & 0.054 ns & 0.94 \\
\hline SN.ANS & 85.75 & 4.65 & 86.01 & 4.62 & 1.854 & 0.072 ns & 0.63 \\
\hline Co-A & 81.09 & 6.82 & 81.24 & 6.73 & 2.029 & 0.051 ns & 0.33 \\
\hline A-NPerp & 1.02 & 3.27 & 0.93 & 3.38 & 0.967 & $0.340 \mathrm{~ns}$ & 0.41 \\
\hline Pg-NPerp & -1.43 & 6.80 & -1.53 & 6.99 & 0.620 & $0.539 \mathrm{~ns}$ & 0.68 \\
\hline SN.GoGn & 36.38 & 5.99 & 36.22 & 6.07 & 1.667 & 0.104 ns & 0.42 \\
\hline SN.Gn & 67.63 & 4.80 & 67.52 & 4.85 & 1.551 & 0.129 ns & 0.33 \\
\hline SN.OP & 22.33 & 10.41 & 22.09 & 10.48 & 1.603 & 0.117 ns & 0.67 \\
\hline 1.NA & 24.65 & 7.85 & 25.02 & 7.52 & 1.966 & $0.057 \mathrm{~ns}$ & 0.84 \\
\hline $1-N A$ & 2.27 & 3.33 & 2.41 & 3.37 & 1.907 & $0.064 \mathrm{~ns}$ & 0.33 \\
\hline 1.SN & 105.70 & 8.12 & 106.02 & 8.16 & 1.514 & 0.138 ns & 0.94 \\
\hline 1.PP & 111.12 & 8.01 & 111.09 & 8.20 & 0.158 & $0.875 \mathrm{~ns}$ & 0.72 \\
\hline 1.NB & 23.45 & 5.60 & 23.84 & 5.85 & 1.557 & $0.128 \mathrm{~ns}$ & 1.10 \\
\hline $1-N B$ & 3.15 & 3.00 & 3.29 & 3.08 & 2.489 & $0.017^{*}$ & 0.28 \\
\hline IMPA & 85.39 & 6.76 & 85.65 & 6.77 & 1.083 & $0,286 \mathrm{~ns}$ & 1.03 \\
\hline
\end{tabular}

ns = non significant statistical difference. ${ }^{*}$ = statistically significant difference $(p<0.05)$

\section{STATISTICAL METHODS}

Descriptive statistics was performed for all data in the sample: Initial and final ages, treatment time $\left(\mathrm{T}_{2}-\mathrm{T}_{1}\right)$ and cephalometric variables analyzed in the study periods. The normality of data distribution was assessed by the Kolmogorov-Smirnov, which revealed that all groups passed the normality criteria.

Two-way analysis of variance was applied for comparison between groups and gender, initial age, treatment time, ANB and A-NPerp, to verify the similarity of data at treatment onset.

Since the groups has different severities (ANB and A-NPerp) at $T_{1}$ and the statistical analysis might be influenced by this factor and not only by the difference between groups, comparison between groups was performed by the analysis of covariance (ANCOVA), using the measurements ANB and A-NPerp as co-variables, to take these initial differences into account.

Table 3 - Dental and skeletal cephalometric variables.

\begin{tabular}{|c|c|}
\hline \multicolumn{2}{|c|}{ Facial convexity } \\
\hline 1) & NAP: Angle between the NA and AP lines \\
\hline 2) & ANB: Angle between the NA and NB lines \\
\hline \multicolumn{2}{|c|}{ Sagittal position of the apical bases } \\
\hline 3) & SNA: Angle between the SN and NA lines \\
\hline 4) & SNB: Angle between the SN and NB lines \\
\hline 5) & SND: Angle between the SN and ND lines \\
\hline 6) & SN.ANS: Angle between the SN line and the anterior nasal spine point \\
\hline 7) & Co-A: Linear distance between points $\mathrm{Co}$ and $\mathrm{A}$ \\
\hline 8) & A-NPerp: Linear distance from point A to the nasion-perpendicular \\
\hline 9) & Pg-NPerp: Linear distance from point Pg to the nasion-perpendicular \\
\hline \multicolumn{2}{|c|}{ Mandibular and occlusal plane rotation } \\
\hline 10) & SN.GoGn: Angle between the SN line and the mandibular plane \\
\hline 11) & SN.Gn: Angle between the SN line and point Gn \\
\hline 12) & $\begin{array}{l}\text { SN.OP: Angle between the SN line and the mandibular occlusal plane } \\
\text { (mandibular occlusal plane - measured from the mean occlusal point } \\
\text { on the intercuspation surface of the mandibular first molars to the } \\
\text { incisal edge of the mandibular central incisor) }\end{array}$ \\
\hline \multicolumn{2}{|r|}{ Inclination of maxillary and mandibular incisors } \\
\hline 13) & 1.NA: Angle between the long axis of the maxillary incisor and the NA line \\
\hline 14) & $\begin{array}{l}\text { 1-NA: Distance between the long axis of the maxillary incisor and } \\
\text { the NA line }\end{array}$ \\
\hline 15) & 1.SN: Angle between the long axis of the maxillary incisor and the SN line \\
\hline 16) & $\begin{array}{l}\text { 1.PP: Angle between the long axis of the maxillary incisor and the } \\
\text { palatal plane }\end{array}$ \\
\hline 17) & 1.NB: Angle between the long axis of the mandibular incisor and the NB line \\
\hline 18) & $\begin{array}{l}\text { 1-NB: Distance between the long axis of the mandibular incisor and } \\
\text { the NB line }\end{array}$ \\
\hline 19) & $\begin{array}{l}\text { IMPA: Angle between the long axis of the mandibular incisor and the } \\
\text { mandibular plane }\end{array}$ \\
\hline
\end{tabular}


Therefore, comparison between groups was performed by two-way analysis of variance (Group - Control and Ankylosis, and Gender - Female and Male), fixed model. If the analysis of variance indicated statistically significant difference, the Tukey test for multiple comparisons was applied. A significance level of 5\% $(\mathrm{p}<0.05)$ was considered for all tests.

All statistical analyses were performed on the software Statistica version 5.1 StatSoft Inc. (Tulsa, USA).

\section{RESULTS}

Table 2 presents the analysis of systematic and casual errors, by analysis by the paired $t$ test and the Dahlberg ${ }^{7}$ formula applied to all study variables. Only the variable (1-NB) presented statistically significant systematic error, yet with a difference of only $0.14 \mathrm{~mm}$. The casual error ranged from $0.28 \mathrm{~mm}(1-\mathrm{NB})$ to $1.10^{\circ}$ (1.NB).

Table 5 displays the cephalometric measurements analyzed during the treatment period $\left(T_{1}\right.$ and $\left.T_{2}\right)$ for

Table 4 - Comparison of initial and final ages, treatment time, ANB and A-NPerp between groups.

\begin{tabular}{|c|c|c|c|c|c|c|c|c|c|}
\hline \multirow{2}{*}{ Group } & \multirow{2}{*}{ Gender } & \multicolumn{2}{|c|}{ Initial age } & \multicolumn{2}{|c|}{ Treatment time } & \multicolumn{2}{|c|}{ ANB } & \multicolumn{2}{|c|}{ A-NPerp } \\
\hline & & Mean & SD & Mean & SD & Mean & SD & Mean & SD \\
\hline \multirow{2}{*}{ Control } & M & 91.90 & 9.76 & 11.60 & 8.14 & 2.90 & 2.86 & 1.71 & 4.32 \\
\hline & F & 93.00 & 10.13 & 9.40 & 4.45 & 1.86 & 1.66 & 2.44 & 3.45 \\
\hline \multirow{2}{*}{ Ankylosis } & M & 87.25 & 16.02 & 11.10 & 4.38 & -0.54 & 3.52 & -1.13 & 3.15 \\
\hline & F & 85.38 & 13.50 & 10.50 & 3.21 & -0.65 & 3.00 & -0.66 & 2.79 \\
\hline \multirow{3}{*}{ Anova } & $p$ group & $0.147 \mathrm{~ns}$ & & $0.861 \mathrm{~ns}$ & & $0.002 *$ & & $0.010 *$ & \\
\hline & p gender & $0.926 \mathrm{~ns}$ & & $0.416 \mathrm{~ns}$ & & 0.524 ns & & $0.587 \mathrm{~ns}$ & \\
\hline & p interaction & $0.721 \mathrm{~ns}$ & & $0.641 \mathrm{~ns}$ & & $0.607 \mathrm{~ns}$ & & $0.906 \mathrm{~ns}$ & \\
\hline
\end{tabular}

ns $=$ statistically non significant difference. ${ }^{*}=$ statistically significant difference $(p<0.05)$.

Table 5 - Mean and standard deviation of cephalometric measurements obtained for the study groups at $T_{1}$ and $T_{2}$

\begin{tabular}{|c|c|c|c|c|c|c|c|c|}
\hline \multicolumn{9}{|c|}{ Mean and standard deviation of measurements obtained for the sample groups } \\
\hline \multirow{2}{*}{$\begin{array}{l}\text { Control } \\
\text { female }\end{array}$} & \multicolumn{2}{|c|}{ Control male } & \multicolumn{2}{|c|}{ Ankylosis female } & \multicolumn{2}{|c|}{ Ankylosis male } & \multicolumn{2}{|c|}{ Cephalometric measurement } \\
\hline & $\mathrm{T}_{1}$ & $T_{2}$ & $\mathrm{~T}_{1}$ & $T_{2}$ & $\mathrm{~T}_{1}$ & $T_{2}$ & $\mathrm{~T}_{1}$ & $\mathbf{T}_{2}$ \\
\hline NAP & $3.49 \pm 4.89$ & $5.22 \pm 4.63$ & $5.61 \pm 5.98$ & $6.00 \pm 5.13$ & $-0.45 \pm 7.67$ & $7.07 \pm 8.18$ & $-0.54 \pm 8.41$ & $6.49 \pm 7.44$ \\
\hline SNA & $80.35 \pm 4.81$ & $81.13 \pm 5.91$ & $83.2 \pm 5.31$ & $83.47 \pm 5.44$ & $81.25 \pm 5.05$ & $84.19 \pm 5.35$ & $80.19 \pm 2.87$ & $82.26 \pm 3.27$ \\
\hline SNB & $78.49 \pm 4.65$ & $78.35 \pm 5.18$ & $80.4 \pm 5.49$ & $80.11 \pm 4.82$ & $82.13 \pm 4.16$ & $81.05 \pm 4.04$ & $80.71 \pm 3.45$ & $79.25 \pm 2.61$ \\
\hline ANB & $1.86 \pm 1.66$ & $2.78 \pm 1.80$ & $2.80 \pm 2.81$ & $3.36 \pm 2.47$ & $-0.65 \pm 3.00$ & $3.23 \pm 3.61$ & $-0.52 \pm 3.55$ & $3.02 \pm 3.73$ \\
\hline SND & $75.23 \pm 4.77$ & $75.18 \pm 5.24$ & $77.09 \pm 5.41$ & $77.18 \pm 4.89$ & $77.81 \pm 3.31$ & $77.20 \pm 3.39$ & $76.65 \pm 3.45$ & $75.7 \pm 2.59$ \\
\hline SN.ANS & $85.25 \pm 4.41$ & $87.50 \pm 6.54$ & $87.30 \pm 4.24$ & $88.1 \pm 4.82$ & $86.25 \pm 4.85$ & $88.20 \pm 5.41$ & $84.6 \pm 4.01$ & $86.8 \pm 4.03$ \\
\hline Co-A & $79.05 \pm 7.80$ & $81.44 \pm 7.70$ & $83.20 \pm 4.88$ & $86.71 \pm 5.4$ & $74.68 \pm 3.57$ & $79.15 \pm 4.77$ & $76.42 \pm 2.26$ & $80.43 \pm 4.76$ \\
\hline A-NPerp & $1.71 \pm 4.32$ & $2.90 \pm 4.82$ & $2.44 \pm 3.45$ & $2.74 \pm 3.07$ & $-1.14 \pm 3.15$ & $1.40 \pm 3.50$ & $-0.66 \pm 2.79$ & $0.67 \pm 3.12$ \\
\hline Pg-NPerp & $0.28 \pm 8.66$ & $1.12 \pm 8.85$ & $-0.39 \pm 7.66$ & $-0.12 \pm 6.44$ & $-2.16 \pm 5.89$ & $-3.46 \pm 6.33$ & $-1.28 \pm 6.51$ & $-4.13 \pm 5.42$ \\
\hline SN.GoGn & $35.84 \pm 5.39$ & $36.44 \pm 6.21$ & $35.26 \pm 6.81$ & $35.86 \pm 5.48$ & $35.80 \pm 5.88$ & $37.71 \pm 6.17$ & $33.83 \pm 5.55$ & $35.5 \pm 4.71$ \\
\hline SN.Gn & $67.76 \pm 3.89$ & $68.59 \pm 4.23$ & $67.02 \pm 6.27$ & $67.50 \pm 5.36$ & $65.71 \pm 4.05$ & $67.24 \pm 3.85$ & $65.00 \pm 4.78$ & $66.77 \pm 3.85$ \\
\hline SN.OP & $21.43 \pm 5.54$ & $19.18 \pm 4.97$ & $23.02 \pm 9.76$ & $21.23 \pm 9.1$ & $31.63 \pm 11.83$ & $21.21 \pm 11.77$ & $24.92 \pm 11.07$ & $22.19 \pm 8.35$ \\
\hline 1.NA & $27.05 \pm 6.30$ & $25.97 \pm 4.87$ & $18.26 \pm 7.51$ & $22.29 \pm 3.91$ & $25.42 \pm 10.47$ & $27.51 \pm 7.6$ & $18.72 \pm 9.50$ & $19.83 \pm 9.59$ \\
\hline $1-N A$ & $1.69 \pm 2.40$ & $3.47 \pm 1.63$ & $0.30 \pm 3.77$ & $2.83 \pm 1.86$ & $0.04 \pm 4.47$ & $2.74 \pm 3.61$ & $-1.60 \pm 2.26$ & $0.84 \pm 3.42$ \\
\hline $1 . S N$ & $107.4 \pm 7.09$ & $107.1 \pm 4.63$ & $101.46 \pm 7.48$ & $105.76 \pm 7.61$ & $106.67 \pm 10.24$ & $111.63 \pm 6.33$ & $98.99 \pm 9.29$ & $102.1 \pm 8.45$ \\
\hline 1.PP & $116.75 \pm 5.66$ & $112.9 \pm 6.08$ & $105.95 \pm 7.24$ & $109.45 \pm 5.01$ & $110.9 \pm 7.43$ & $115.2 \pm 5.85$ & $104.25 \pm 8.93$ & $107.25 \pm 9.49$ \\
\hline 1.NB & $28.03 \pm 4.69$ & $23.63 \pm 7.44$ & $27.00 \pm 7.40$ & $26.18 \pm 5.38$ & $21.72 \pm 6.13$ & $25.29 \pm 6.09$ & $19.56 \pm 8.21$ & $20.77 \pm 5.66$ \\
\hline $1-N B$ & $3.93 \pm 2.04$ & $3.7 \pm 2.28$ & $3.82 \pm 2.84$ & $3.84 \pm 2.7$ & $0.52 \pm 3.35$ & $3.78 \pm 3.43$ & $1.24 \pm 2.83$ & $1.97 \pm 3.46$ \\
\hline IMPA & $91.25 \pm 5.73$ & $86.51 \pm 8.96$ & $89.11 \pm 8.43$ & $87.84 \pm 6.33$ & $81.05 \pm 7.94$ & $86.61 \pm 10.56$ & $82.31 \pm 7.42$ & $83.57 \pm 5.11$ \\
\hline
\end{tabular}


Table 6 - Variation of measurements (mean and standard deviation) during treatment ( $T_{2}-T_{1}$ ), and comparison between groups by Analysis of Covariance and the Tukey test.

\begin{tabular}{|c|c|c|c|c|c|c|c|}
\hline \multirow{3}{*}{$\begin{array}{c}\text { Measure- } \\
\text { ments }\end{array}$} & \multicolumn{2}{|c|}{ Female } & \multicolumn{2}{|c|}{ Male } & \multicolumn{3}{|c|}{ ANCOVA } \\
\hline & Control & Ankylosis & Control & Ankylosis & \multicolumn{3}{|c|}{$\mathbf{p}$} \\
\hline & mean $\pm S D$ & mean \pm SD & mean \pm SD & mean \pm SD & Group & Gender & Interaction \\
\hline \multicolumn{8}{|c|}{ Sagittal skeletal measurements } \\
\hline NAP & $1.73 \pm 3.87^{a}$ & $7.52 \pm 5.06^{b}$ & $0.39 \pm 4.00^{a}$ & $7.03 \pm 5.33^{b}$ & $0.007^{*}$ & 0.651 & 0.911 \\
\hline SNA & $0.78 \pm 2.13$ & $2.94 \pm 3.07$ & $0.27 \pm 2.50$ & $2.08 \pm 2.16$ & 0.109 & 0.459 & 0.761 \\
\hline SNB & $-0.14 \pm 1.31$ & $-1.08 \pm 1.81$ & $-0.28 \pm 1.52$ & $-1.46 \pm 1.61$ & 0.083 & 0.618 & 0.833 \\
\hline ANB & $0.92 \pm 1.54^{a}$ & $3.88 \pm 2.49^{b}$ & $0.56 \pm 1.81^{\mathrm{a}}$ & $3.54 \pm 2.71^{b}$ & $0.005^{\star}$ & 0.730 & 0.898 \\
\hline SND & $-0.05 \pm 1.48$ & $-0.61 \pm 1.39$ & $0.09 \pm 1.63$ & $-0.95 \pm 1.75$ & 0.368 & 0.780 & 0.697 \\
\hline SN.ANS & $2.25 \pm 4.28$ & $1.95 \pm 3.45$ & $0.80 \pm 2.73$ & $2.20 \pm 2.21$ & 0.700 & 0.584 & 0.441 \\
\hline Co-A & $2.39 \pm 1.62$ & $4.47 \pm 3.41$ & $3.51 \pm 4.92$ & $4.01 \pm 3.43$ & 0.655 & 0.517 & 0.351 \\
\hline A-NPerp & $1.19 \pm 2.58$ & $2.54 \pm 2.80$ & $0.30 \pm 1.77$ & $1.34 \pm 2.60$ & 0.771 & 0.263 & 0.747 \\
\hline Pg-NPerp & $0.84 \pm 3.99^{a}$ & $-1.30 \pm 2.49^{b}$ & $0.26 \pm 2.83^{a}$ & $-2.85 \pm 2.99^{b}$ & $<0.001^{*}$ & 0.343 & 0.607 \\
\hline \multicolumn{8}{|c|}{ Vertical skeletal measurements } \\
\hline SN.GoGn & $0.61 \pm 1.77$ & $1.91 \pm 1.83$ & $0.61 \pm 2.63$ & $1.67 \pm 1.69$ & 0.447 & 0.990 & 0.741 \\
\hline SN.Gn & $0.83 \pm 1.05$ & $1.53 \pm 1.20$ & $0.48 \pm 1.81$ & $1.76 \pm 1.66$ & 0.378 & 0.934 & 0.637 \\
\hline SN.OP & $-2.26 \pm 1.85^{a}$ & $-10.42 \pm 6.52^{b}$ & $-1.80 \pm 3.04^{a}$ & $-2.73 \pm 6.97^{a}$ & $<0.001^{*}$ & $0.005^{\star}$ & $0.035^{*}$ \\
\hline \multicolumn{8}{|c|}{ Dental measurements } \\
\hline 1.NA & $-1.08 \pm 5.33$ & $2.09 \pm 8.82$ & $4.02 \pm 6.71$ & $1.11 \pm 9.33$ & 0.555 & 0.475 & 0.263 \\
\hline $1-N A$ & $1.78 \pm 2.48$ & $2.70 \pm 3.88$ & $2.53 \pm 3.17$ & $2.43 \pm 2.58$ & 0.253 & 0.939 & 0.685 \\
\hline $1 . \mathrm{SN}$ & $-0.31 \pm 4.87$ & $4.97 \pm 9.87$ & $4.30 \pm 7.54$ & $3.11 \pm 10.04$ & 0.328 & 0.665 & 0.265 \\
\hline 1.PP & $-3.85 \pm 8.48$ & $4.30 \pm 4.50$ & $3.50 \pm 4.94$ & $3.00 \pm 11.37$ & 0.154 & 0.249 & 0.107 \\
\hline 1.NB & $-4.40 \pm 3.99^{a}$ & $3.57 \pm 6.83^{b}$ & $-0.82 \pm 5.15^{a}$ & $1.21 \pm 4.44^{b}$ & $0.001^{*}$ & 0.855 & 0.080 \\
\hline $1-N B$ & $-0.23 \pm 1.14^{a}$ & $3.26 \pm 3.46^{b}$ & $0.02 \pm 1.39^{a}$ & $0.73 \pm 2.74^{b}$ & $0.001^{*}$ & 0.076 & 0.087 \\
\hline IMPA & $-4.75 \pm 4.48^{a}$ & $5.56 \pm 10.32^{b}$ & $-1.26 \pm 5.57^{a}$ & $1.26 \pm 4.73^{b}$ & $0.001^{*}$ & 0.679 & 0.076 \\
\hline
\end{tabular}

* - statistically significant difference $(p<0.05)$. Groups with similar letters do not have statistically significant difference to each other.

each study group (female control, female ankylosis, male control, male ankylosis).

The statistical comparison between groups reveals that they were compatible considering the initial age and treatment time. However, there was significant difference in the variables ANB and A-NPerp (Table 4), which led to the utilization of analysis of covariance for comparison between groups.

The statistical analysis revealed that the cephalometric measurements were not influenced by gender, except for the variable SN.OP. The changes in cephalometric measurements occurred in the same direction and magnitude for both genders (Table 6). There was statistically significant difference between groups in the variation of sagittal measurements NAP, ANB and Pg-NPerp, the vertical measurement SN.OP, and the dental measurements 1.NB, 1-NB and IMPA (Table 6).

\section{DISCUSSION}

The early treatment of anterior crossbite with Class III malocclusion has the orthopedic goal to promote forward displacement of the maxillary dental arch, with downward and forward advancement of the growth direction of the maxilla. ${ }^{1,2,5,6,9-13,15-18,21,23}$ For that purpose, the maxillary protraction after orthopedic maxillary expansion has been used by most orthodontists, with favorable immediate results in $90 \%$ of patients treated in the deciduous and mixed dentitions ${ }^{4}$ with a relatively short treatment time of nearly 8 months. ${ }^{18}$ Regardless of the influence of facial growth on the long-term posttreatment stability, the immediate goal of orthopedic treatment for the Class III malocclusion is to potentiate the skeletal changes rather than the dental compensation, by the utilization of strong anchorage ${ }^{1}$ This study addresses the maxillary protraction, more specifically to 
analyze the influence of intentional ankylosis of deciduous canines to reinforce the anchorage, a protocol established at the Hospital for Rehabilitation of Craniofacial Anomalies of University of São Paulo. ${ }^{19,20}$ In this treatment protocol, the deciduous canines are ankylosed before orthopedic expansion and maxillary protraction, in the deciduous or early mixed dentition stages. ${ }^{19}$

This therapeutic possibility was developed to optimize the forward displacement of point $\mathrm{A}$ and involves different specialties in addition to Orthodontics, such as Surgery and Endodontics, thus not being promptly accepted by patients and caretakers. ${ }^{19}$ For this reason, the cost-benefit relationship of intentional ankylosis should be individually considered, being indicated for cases of anterior crossbite and greater severity of maxillary deficiency, especially when dental anchorage in the maxillary arch is not reliable and satisfactory. ${ }^{19,21}$ The ankylosis should be contraindicated in cases of Class III malocclusion assigned only to mandibular prognathism, because of the unpredictable mandibular growth after treatment and the normal maxillary positioning on the face of these patients. ${ }^{19,21}$

The results revealed that the convexity angles, represented by the angular measurements NAP and ANB had a significant impact by the orthopedic mechanics of maxillary protraction (Table 6), which is also observed in studies analyzing the effects of maxillary protraction in the treatment of Class III malocclusion. ${ }^{3,10,18,20}$ In addition to the alterations in facial convexity, the soft tissue profile was improved. The intentional ankylosis of deciduous canines increased the facial convexity (Table 6), as an immediate effect of maxillary protraction, which does not depend on facial growth.

The improved facial convexity is assigned to the sagittal change in the maxillary and mandibular apical bases. The literature demonstrated that the maxilla tends to present forward displacement with maxillary protraction. $3,5,6,8,9,10,12,13,17,18,21,22$ However, this displacement was not statistically significant for the alveolar portion, represented by the SNA angle and the basal portion, characterized by the SN.ANS angle (Table 6). Even though no statistically significant difference was observed between groups in the SNA angle, this variable presented a greater mean alteration in the Ankylosis Group (2.94 in females and 2.07 in males) than the Control Group (0.78 in males and 0.27 in males), demonstrating that the forward displacement of point A was greater in the
Ankylosis Group (Table 5),explaining the significant increase in facial convexity evaluated by the variables NAP and ANB in the Ankylosis Group compared to the Control Group (Table 6).

The SNB angle presented more posterior positioning, especially in the group with intentional ankylosis of deciduous canines (Table 5). The sagittal improvement in point $\mathrm{B}$ is related to the mandibular rotation during maxillary protraction. ${ }^{13}$ Indirectly, the increased angle of facial convexity is also influenced by the mandibular rotation. These changes promoted by maxillary pro-

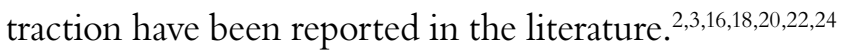
In the present study groups, the angles SN.GoGn and NS.Gn demonstrated that the mandible presented clockwise rotation, as mentioned in the literature, $3,4,5,8$ yet without statistical significance. This behavior was similar in the two groups, indicating that ankylosis did not influence the mandibular rotation (Table 6).

The occlusal plane in the present study did not follow the mandibular rotation. This occurred in clockwise direction, while the occlusal plane presented counterclockwise rotation (Table 5). Due to the dental age of the sample, in the deciduous and early mixed dentition stages, the references taken to identify the mandibular occlusal plane, (mean occlusal point on the intercuspation surface of maxillary and mandibular first molars to the incisal edge of the permanent mandibular central incisors), were still in the period of eruption, with important variation in vertical direction. The vertical instability of the reference teeth at this period of occlusal development may explain the divergent behavior between the mandibular and occlusal planes. There is concern to maintain the inclination of the occlusal plane during maxillary protraction, by applying the elastic at the region of deciduous canines, directly on the fixed Haas expander. ${ }^{15}$ The maxillary protraction from the posterior region is contraindicated in most patients because it lowers the posterior portion of the maxilla, ${ }^{8}$ while protraction from the canines region controls this rotation effect during maxillary protraction. ${ }^{21}$

The linear measurements representing the sagittal behavior of the apical bases were defined by the distances Co-A, A-NPerp and Pg-NPerp. The point A presented forward positioning in relation to the cranial base in both groups (Table 5). The displacement of point A reflects the increased maxillary length. The literature has demonstrated that maxillary protraction induces an 
increase in maxillary length (ANS-PNS) compared to an untreated control group. ${ }^{21}$ However, the forward displacement of point A was not influenced by the intentional ankylosis of deciduous canines, even though the maxillary displacement was greater in the group with ankylosis (Tables 5 and 6). Conversely, the point Pog exhibited more posterior positioning in relation to the line NPerp in the group with ankylosis (Table 6). The importance of the behavior of points A and Pog refers to their influence on facial convexity.

The interpretations related to the dental changes should consider that the permanent incisors were still in the period of eruption, since the patients were in the deciduous and early mixed dentition stages. Some changes in the tipping of these teeth occur during occlusion development and thus should be carefully analyzed.

The intentional ankylosis of deciduous canines did not influence the maxillary incisors. The literature unanimously reports the dental effect induced by orthopedic mechanics, with buccal tipping of maxillary incisors, ${ }^{5,6}$ regardless of the accomplishment of intentional ankylosis of deciduous canines. ${ }^{20}$ No exclusively orthopedic effect may be produced by tooth-supported appliances. ${ }^{19}$ The question is if the intentional ankylosis of deciduous canines would reduce the orthodontic effect. Comparison between intentional ankylosis and the control group did not reveal difference between groups, indicating that an- kylosis did not influence the dental compensation in the maxillary arch (Table 6). This result clearly demonstrates that the intentional ankylosis of deciduous canines may potentiate the orthopedic effect induced by maxillary protraction, yet does not avoid dental compensation in the maxilla, represented by the buccal tipping of maxillary incisors, except for the sample group female control (Table 5).

The mandibular incisors exhibited an unexpected change, with an increase in buccal tipping during orthopedic treatment in the group with intentional ankylosis. In general, reduced tipping of these teeth is expected in the orthopedic treatment for the Class III malocclusion, as part of the compensatory mechanism. ${ }^{13}$ This result may be related to the treatment period, in the early mixed dentition stage, when the permanent incisors erupt. Another probable explanation for the behavior of mandibular incisors is the increased overjet provided by the maxillary advancement in the group with intentional ankylosis, providing additional space for buccal tipping of mandibular incisors.

\section{CONCLUSIONS}

The null hypothesis was accepted, because it was concluded that intentional ankylosis enhanced the sagittal response of the apical bases, as demonstrated by the alteration in Pg-NPerp and the increase in facial convexity angles (NAP and ANB). 
1. Baccetti T, McGill JS, Franchi L, McNamara JA Jr, Tollaro I. Skeletal effects of early treatment of Class III malocclusion with maxillary expansion and face-mask therapy. Am J Orthod Dentofacial Orthop. 1998;113(3):333-43.

2. Baik HS. Clinical results of the maxillary protraction in Korean children. Am J Orthod Dentofacial Orthop. 1995;108(6):583-92.

3. Chong YH, Ive JC, Artun J. Changes following the use of protraction headgear for early correction of Class III malocclusion. Angle Orthod. 1996:66(5):351-62.

4. Delaire J. Maxillary development revisited: relevance to the orthopedic treatment of Class III malocclusions. Eur J Orthod. 1997;19(3):289-311.

5. Dahlberg G. Statistical methods for medical and biological students. New York: Interscience; 1940

6. Gallagher RW, Miranda F, Buschang PH. Maxillary protraction: treatment and postreatment effects. Am J Orthod Dentofacial Orthop. 1998;113(6):612-9

7. Göyenç Y, Ersoy S. The effect of a modified reverse headgear force applied with a facebow on the dentofacial structures. Eur J Orthod 2004;26(1):51-7

8. Houston WJ. The analysis of errors in orthodontic measurements. Am J Orthod. 1983:83(5):382-90.

9. Ishii H, Morita S, Takeuchi Y, Nakamura S. Treatment effect of combined maxillary protraction and chincap appliance in severe skeletal Class III cases. Am J Orthod Dentofacial Orthop. 1987:92(4):304-12.

10. Kapust AJ, Sinclair PM, Turley PK. Cephalometric effects of face mask/ expansion therapy in Class III children: a comparison of three ages groups. Am J Orthod Dentofacial Orthop. 1998;113(2):204-12.

11. Kiliçoglu H, Kirliç Y. Profile changes in patients with Class III malocclusions after Delaire mask therapy. Am J Orthod Dentofacia Orthop. 1998;113(4):453-62.

12. MCNamara JA Jr. An orthopedic approach to the treatment of Class III malocclusion in young patients. J Clin Orthod. 1987;21(9):598-608.

13. Mermigos J, Full CA, Andreasen G. Protraction of the maxillofacial complex. Am J Orthod Dentofacial Orthop. 1990;98(1):47-55.
14. Ngan P. Hägg U, Yiu C, Merwin D, Wei SH. Soft tissue and dentoskeletal profile changes associated with maxillary expansion and protraction headgear treatment. Am J Orthod Dentofacial Orthop. 1996;109(1):38-49

15. Ngan P, Hägg U, Yiu C, Merwin D, Wei SH. Treatment response to maxillary expansion and protraction. Eur J Orthod. 1996:18(2):151-68

16. Ngan PW, Hagg U, Yiu C, Wei SH. Treatment response and long-term dentofacial adaptations to maxillary expansion and protraction. Semin Orthod. 1997:3(4):255-64

17. Saadia M, Torres E. Sagittal changes after maxillary protraction with expansion in Class III patients in the primary, mixed and late mixed dentitions: a longitudinal retrospective study. Am J Orthod Dentofacial Orthop. 2000; 117(6):669-80

18. Shanker S, Ngan P, Wade D, Beck M, Yiu C, Hägg U, Wei SH. Cephalometric A point changes during and after maxillary protraction and expansion. Am J Orthod Dentofacial Orthop. 1996:110(4):423-30.

19. Silva Filho OG, Magro AC, Capelozza Filho L. Early treatment of the Class III malocclusion with rapid maxillary expansion and maxillary protraction. Am J Orthod Dentofacial Orthop. 1998;113(2):196-203.

20. Silva Filho OG, Ozawa TO, Okada CH, Okada HY, Carvalho RM. Intentional ankylosis of deciduous canines to reinforce maxillary protraction. J Clin Orthod. 2003:37(6):315-20.

21. Silva Filho OG, Ozawa TO, Okada CH, Okada HY, Dahmen L. Anquilose intencional dos caninos decíduos como reforço de ancoragem para a tração reversa da maxila. Estudo cefalométrico prospectivo. Rev Dental Press Ortod Ortop Facial. 2006;11(6):35-44

22. Sung SJ, Baik HS. Assessment of skeletal and dental changes by maxillary protraction. Am J Orthod Dentofacial Orthop. 1998;114(5):492-502.

23. Takada K, Petdachai S, Sakuda M. Changes in dentofacial morphology in skeletal Class III children treated by a modified maxillary protraction headgear and a chin cup: a longitudinal cephalometric appraisal. Eur J Orthod. 1993:15(3):211-21.

24. Turley PK. Orthopedic correction of Class III malocclusion: Retention and phase II therapy. J Clin Orthod. 1996:30(6):313-24 